\title{
Örgütleyici Yapı İskelesi Tekniğinin Öğretmen Adaylarının Not Alma Becerilerine ve Akademik Başarılarına Etkisi
}

\section{The Effect of Organized Scaffolding Technique on Note-Taking Skills and Academic Achievement of Pre-Service Teachers}

\author{
Buket ASLANDAĞ $\breve{G}^{1} \quad$ Gökhan ÇETINNKAYA ${ }^{2}$ \\ - Geliş Tarihi: 21.05.2018 • Kabul Tarihi: 17.09.2018 • Yayın Tarihi: 01.01.2019
}

\begin{abstract}
$\ddot{\mathbf{O} z}$
Not alma, öğrenme-öğretme sürecinde öğrenenin dikkatini öğrenilecek konuya vermesini sağlayan, etkili dinleme becerisi geliştirmesine yardımcı olan ve öğrenmenin niteliğini artıran bir eylemdir. Eş zamanlı olarak öğrenenlerin farklı duyularını kullanmalarına olanak tanıyan not alma eylemi etkin bir öğrenme faaliyetinin gerçekleşmesinde önemli bir değişkendir. Not alma sürecinde öğrenenlerin, sürece uyum sağlamakta, öğretmenlerin hızlarına yetişmede veya hazır bulunuşluklarının düşük olduğu durumlarda yeni öğrenme malzemesinin önemli bölümlerini ayırt etmekte sorun yaşamaları olasıdır. Örgütleyici yapı iskelesi not alma tekniği, öğrenenlere anlamlı ve düzenli not almaya ilişkin kolaylık sağlayan bir teknik olarak bazı eğitimciler tarafından tercih edilmektedir. Bu bağlamda, karma nitelikli bu araştırmada katılımcıların not alma biçimleri ile performansları arasındaki ilişkinin saptanması amaçlanmıştır. Araştırmanın çalışma grubunu bir devlet üniversitesindeki RPD Anabilim Dalı öğrencileri oluşturmaktadır. 60 öğrencinin yer aldığ uygulanırken, kontrol grubu deney sürecinde not alma konusunda kendi tercihlerine bırakılmıştır. Elde edilen verilerin çözümlenmesi sonucunda deney grubundaki katılımcıların örgütleyici yapı iskelesi not alma puanları ile konu alanı performans puanları arasında pozitif yönde kuvvetli bir ilişki olduğu görülmüştür. Yapılan yarıyapılandırılmış görüşmeler neticesinde örgütleyici yapı iskelesi not alma tekniğinin katılımcılara konunun bütününe hakim olabilme, ön bilgilerle ilişkilendirebilme, öğretim elemanının hızına uyum sağlayabilme, anlaşılır ve rasyonel not tutabilme gibi üstünlükleri olduğunu ortaya konmuştur.
\end{abstract}

Anahtar sözcükler: yapı iskelesi, not alma, öğretmen adayları

\section{Önerilen Atıf Bilgisi:}

Aslandağ, B. ve Çetinkaya, G. (2019). Örgütleyici yapı iskelesi tekniğinin öğretmen adaylarının not alma becerilerine ve akademik başarılarına etkisi. Pamukkale Üniversitesi Ĕ̌itim Fakültesi Dergisi, $45,190-210$.

\footnotetext{
${ }^{1}$ Dr. Öğr. Üyesi, Niğde Ömer Halisdemir Üniversitesi, Eğitim Fakültesi, Eğitim Programları ve Öğretim Anabilim Dal1, ORCID: 0000-0002-2935-2320, buket.aslandag@gmail.com

${ }^{2}$ Doç. Dr., Pamukkale Üniversitesi, Eğitim Fakültesi, Türkçe Eğitimi Anabilim Dalı, ORCID: 0000-0001-7676-6852 gokhancetinkaya76@hotmail.com
} 


\begin{abstract}
Note-taking is an action that helps the learner to pay attention to the topic to be learned in the learning-teaching process, aids to develop effective listening skills, and enhances the quality of learning. Note-taking enabling the learners to use different senses simultaneously is an important variable in the effective learning process. In the notetaking process, learners may have problems in adaptation to the process, in keeping up with the pace of teachers or in distinguishing important parts of the new learning materials in the situations where they are not ready. Organized scaffolding note-taking technique is preferred by some educators as a technique that provides easiness and meaningful note-taking for learners. Concordantly, the relationship between note-taking styles and academic achievement of the participants was aimed to detect in this mixed study. The working group of the study consisted of undergraduates attending the faculty of education at a state university. In the study where 60 students were involved, the control group was left to their own preference to take notes in the experimental process while being applied Organized scaffolding technique in the experimental group. As a result of the analysis of the data, it was found out that participants in the experimental group had a strong positive relationship between Organized scaffolding grade points and subject area performance scores. In consequence of the semi-structured interviews, it has been revealed that Organized scaffolding technique has the advantages of being able to have a comprehensive knowledge in the subject, to be able to relate to the preliminary information, to adapt to the speed of the instructor, and to keep rational and comprehensible notes.
\end{abstract}

Keywords: scaffolding, note-taking, pre-service teachers

\title{
Giriş
}

Ders anlatımı sürecinde yer alan konuların kalıcılığını sağlamak ve ders sonrasında bu konuları gözden geçirmek için öğrencinin not alması gerekir. Çünkü yazılı olarak saklanan notların gözden geçirilmesi akılda tutmayı kolaylaştırır. Gözden geçirme, öğrencilerin not alınan bilgileri pekiştirmesini, ders konularını yeniden yorumlamasını ve unutulan bilgiyi hatırlamasını sağlar. Fakat öğrencinin aldığı notlar nitelikli değilse gözden geçirme süreci işlevsel olmayacaktır.

Alan yazın incelendiğinde (DeZure, Kaplan ve Deeman, 2001; Bonner ve Holliday, 2006; Rachal, Daigle ve Rachal, 2007) öğrencilerin not alma konusunda yeteri kadar başarılı olmadıkları görülmektedir. Ders anlatım sürecinde önemli noktaları tespit etmek ve bunları belli bir düzen içinde kısa zamanda not almak, öte yandan da dikkatle öğretim elemanını dinlemeyi sürdürmek üst düzey beceri gerektirir. Not alma, kavrama, bilgiyi seçme ve yazılı üretim süreçlerini gerektiren karmaşık bir bilişsel ve dilsel süreçtir. Çünkü not alma eylemi sırasında birçok zihinsel süreç aynı anda gerçekleşir. Öğrenci öğretim elemanına dikkatini vermeli, konuyu anlamalı, not alması gereken önemli noktaları seçmeli ve fiziksel olarak yazmalıdır. Ayrıca tüm bu eylemleri belli bir zaman baskısı altında gerçekleştirmelidir (Friedman, 2017:6). Bir öğrencinin ortalama yazma hızının yaklaşık 0,3 ila 0,4 sözcük/saniye ve bir öğretim elemanının konuşma hızının da yaklaşık 2 ila 3 sözcük/saniye olduğu (Boch \& Piolat, 2005:102) düşünüldügünde durumun zorluğu daha da belirginleşir.

Not alma biçimleri doğrusal (linear) ve doğrusal olmayan (non linear) biçimde iki ulama ayrılabilir. Geleneksel yazılı metin biçimine benzeyen doğrusal not alma öğrencilerin yaygın olarak kullandıkları biçimdir (Piolat, 2001; akt. Friedman, 2017: 10). Buna karşılık, grafik gösterimlerin (graphical representations) kullanıldığı doğrusal olmayan biçim (style) öğrencilere notlarının içeriğini sistematik olarak düzenleme olanağı tanır (Friedman, 2017).

Araştırmacılara (DiVesta ve Gray, 1972; Boch ve Piolat, 2005; Kiewra, 2005; Kobayashi, 2005; Friedman, 2017) göre not almanın iki işlevi vardır. Not almanın birinci işlevi kodlama (encoding), ikinci işlevi ise depolamadır (storage). Notları kaydetme süreci not almanın kodlama işlevidir. Gözden geçirme yapılmasa bile notları kaydetme süreci öğrenmeyi 
sağlar. Çünkü not alma etkinlikleri dikkatin artmasını, belirli düşüncelerin daha ayrıntılı bir biçimde işlenmesini ve ders içeriğinin (lecture material) daha iyi düzenlenmesini sağlar (Kiewra, 1989:149). Öte yandan, yazılı bir biçimde saklanan notların gözden geçirilmesi akılda tutmayı kolaylaştırır. Bu durum da not almanın depolama işlevidir. Not alan öğrenciler, not almayan öğrencilerle karşılaştırıldığında not alan öğrencilerin daha iyi kavradığı görülür. Çünkü not alma öğrencilerin bilgiyi seçerek konuya kulak vermesini gerektirir (Robinson, Katayama, Odom, Hsieh, ve Vanderveeni, 2006:103). Benzer biçimde notlarını gözden geçiren öğrenciler, gözden geçirmeyenlere oranla içeriğin daha önemli noktaları üstünde daha fazla durabildiklerinden konuyu daha iyi kavrarlar. Öte yandan, kişinin kendi aldığı notları gözden geçirmesinin konuyu öğrenmesi ve hatırlaması açısından başkasının aldığı notları gözden geçirmesinden daha fazla yararı olur. Çünkü üretken öğrenme, kişinin bilgiyi ön bilgileriyle bütünleştirerek yeniden düzenlediği etkin bir anlamlandırma sürecidir (Fiorella ve Mayer, 2016:717).

Araştırmalar, öğrencilerin sınıfta ve çalışırken zayıf stratejiler kullandığını göstermektedir (Bonner ve Holliday, 2006; Jairem ve Kiewra, 2009; Chen, 2013; Jacqueline ve Ben, 2015 ). Zayıf stratejiler; zayıf not alma, düşünceleri doğrusal olarak organize etme, parça parça öğrenme ve gereksiz stratejiler kullanma gibi durumlardır. Öğrencilerin ders anlatımından ya da metinden not alma becerileri zayıftır. Ders anlatımı sürecinde öğrenciler dersin önemli noktalarının yaklaşık \%70'ini not almazlar (Kiewra, 1985; Jairam ve Kiewra, 2009). Eksik not alma bir sorundur. Çünkü notlarda kaydedilen önemli noktaların sayısı ile başarı arasında olumlu yönde anlamlı bir ilişki vardır (Kiewra, 1984; Jairam ve Kiewra, 2009). Birçok öğrenci bilgiyi organize etmekte güçlük çeker. Rachal, Daigle ve Rachal'ın (2007) çalışmasının sonuçları, katılımcıların \%66'sının düşünceleri organize etmede sorun yaşadığını, öte yandan \%52'sinin de notlarının dağınık olduğunu kabul ettiğini göstermektedir.

Kiewra (1987), öğrencilerin not almaya ilişkin algılarının, önemli konuları seçmekaydetme durumlarının, konuya olan ilgi ve dikkatlerinin etkili not almaları konusunda belirleyici olduğunu belirtir. Bunun yanında öğretmenin sunuşu etkin bir biçimde örgütlemesi de dişsal bir etkiye sahiptir. Dersi dinleme ve not alma sürecinde öğrencilerin özellikle önemli bilgiyi seçme ya da not alınan konuyu bağlı olduğu başlığın altına yerleştirme konusunda zorluk yaşadıkları görülür. Öğrencilerin zayıf not alma becerilerinden ötürü konulara ilişkin bütünsel ya da bölümsel notların öğretim elemanı tarafından sağlanması önerilir (Konrad, Joseph \& Eveleigh 2009). Daha önceden de söz edildiği gibi not alma önemli bir öğrenme stratejisidir. Öğrencinin, bilgiyi ön bilgileriyle bütünleştirerek yeniden düzenlemesine olanak sağlayan etkin bir anlamlandırma sürecidir. Yaşanan bu zorluğun önüne geçmek için öğretmenlerin öğretimi, öğrenmeyi kolaylaştıracak şekilde örgütlemesi beklenir. Kiewra, Benton, Kim, Risch ve Christensen'e (1995) göre öğretim elemanının doğrusal çerçevelere ilişkin başlıklar ve alt başlıklar sunması öğrencilerin seçici dikkatini artırır ve öğrencilerin önemli noktaları not edebilmesini sağlar. Alanyazında yer alan bu öneriler öğrencilerin not alma sürecinde desteğe gereksinim duyduğunu ve bu gereksinimi giderecek başat eylemin de örgütleme olduğunu belirtir. Bu nedenle not alma sürecinde işe koşulabilecek seçeneklerden biri de örgütleyici yap1 iskelesi tekniğidir.

Yapı iskelesi, bina yapımında işçileri destekleyen, binanın dışındaki düzenektir. Eğitim bağlamında, öğrencilerin karmaşık bir görevi bitirmesine ya da kendi başlarına 
Örgütleyici Yapı İskelesi Tekniğinin Öğretmen Adaylarının Not Alma Becerilerine ve Akademik Başarılarına Etkisi

başaramayacakları bir hedefe ulaşmasına yardımcı olan desteğe atıfta bulunur (Hu, 2006). Öğretim iskelesi birçok özelliğe sahiptir: öğrencileri destekler; bir araç olarak işlev görür; öğrencilerin yapabileceklerini genişletir; öğrencilerin kendi başlarına tamamlayamadığı bir görevi yerine getirmelerine olanak tanır ve gerektiğinde öğrencilere yardımcı olmak için seçici olarak kullanılır (Hu, 2006:44).

Aşağıda yapı iskelesi uygulamalarıyla öğrencinin yakınsak gelişim alanı çerçevesinde ulaşılması istenen düzeye ipuçları, ara çözümler, veriler yoluyla ulaştırılabileceğine ilişkin bir çizelge yer almaktadır.

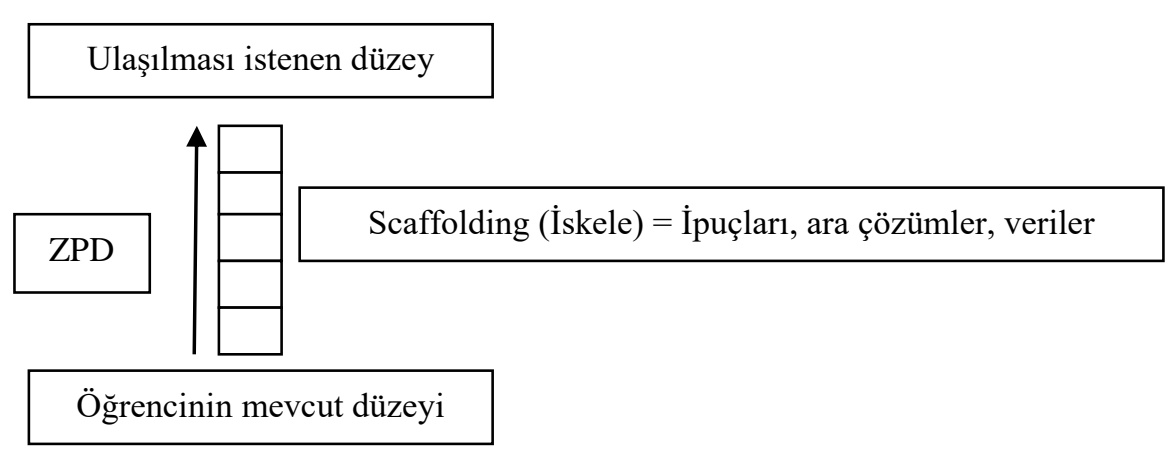

Şekil 1. Yakınsak gelişim alanı \& Yapı İskelesi Modeli (Baki'den (2008:314) uyarlanmıştır.)

Bransford, Brown ve Cocking'e (2000:104) göre yapı iskelesi öğretim sürecine bir dizi olumlu katkı sunar. Buna göre yapı iskelesinin katkıları şu şekildedir:

-Öğrencilerin konuya olan ilgilerini artırır ve onları güdüler.

- Konuyu kolaylaştırarak öğrenciler için üstesinden gelinebilir ve başarılabilir kılar.

- Bir dizi yönergeler sunarak öğrencilerin hedefe ulaşmalarında onlara yardımcı olur.

- Öğrencilerin kaygılarını düşürür.

- Gerçekleştirilecek etkinliğe ilişkin beklentileri açık bir biçimde tanımlar ve modeller.

Yapı iskelesi tekniğinin okuma/yazma becerilerinin kazandırılması (Dickson, Chard ve Simmons, 1993), üst bilişsel stratejilerin öğretimi (Barak ve Carla,1992), matematik öğretimi (Amiripour, Amir-Mofidi ve Shahvarani, 2012), sorgulamaya dayalı öğretim (Arı, 2017) gibi farklı konuların öğretim ortamında yer bulduğu görülür. Bu çalışmada ise örgütleyici yap1 iskelesi tekniği öğretim ortamına aktarılmıştır. Örgütleyici yapı iskelesi tekniğinde öğrencilere aktarılacak konunun ana hatlarını içeren bir form hazırlanır (bkz. Ek 1:Örnek form). Bu form dersin başında öğrencilere verilerek öğrencilerin bu form üzerine not alması sağlanır (bkz. Ek 2: Örnek Öğrenci notu). Örgütleyici yapı iskelesi, öğrencilerin yeni öğrenecekleri konu hakkında yapı iskeleti oluşturarak öğrenenlerin artalan bilgileriyle uyumlu anlamlar ve algılar üreterek bilgiyi rahatlıkla organize etmelerini sağlamalarını amaçlayan bir not alma tekniğidir.

\section{Çalıșmanın Önemi ve Amacı}

Çalışmalar, ders notlarının niteliği ile öğrenme arasında anlamlı bir ilişki olduğunu göstermektedir (Williams \& Worth, 2002; Koboyashi, 2006; Nakayama, Mutsuura and Yamamoto, 2016; Friedman, 2017). Öğrencilerin not alma becerilerinin istendik düzeyde 
olmaması, derste işlenen konuları tam olarak öğrenememelerine ve hatırlayamamalarına neden olur. Yukarıda da sözü edildiği gibi, not alma karmaşık bir süreçtir. Bu yüzden öğretim elemanının süreci kolaylaştırıcı katkılar sağlaması gerekir. Çalışmalar incelendiğinde çeşitli yap1 iskelesi etkinliklerinin öğrencilerin okuduğunu anlama ve yazma becerileri üzerinde olumlu etkileri olduğu görülür (Magno, 2010; Poorahmadi, 2010; Khosravi, 2017). Not alma sürecine dönük ise örgütleyici yap1 iskelesi tekniği içeren herhangi bir çalışmaya rastlanmamıştır. Ayrıca, Türkçe alan yazında not alma sürecine dönük yeteri kadar çalışma yer almamaktadır. Not alma becerisinin öğrenme ve hatırlama üzerindeki etkisi düşünüldüğünde ülkemizde konuyla ilgili yeterli çalışma bulunmamasının eksiklik olduğu söylenebilir. Yapılan az sayıda çalışmanın konusu genel olarak öğrencilerin dinlerken not alma stilleri ve derste not almanın öğrenme ve hatırlama düzeyine etkisi üzerinedir (Oğuz, 1999; Çetingöz, 2006; Durukan ve Maden, 2010; Tabak ve Karadüz, 2016).

$\mathrm{Bu}$ çalışmanın temel amacı, ipucu olarak örgütleyici yapı iskelesi kullanmanın öğretmen adaylarının not alma becerileri üzerinde etkisi olup olmadığını ortaya koymaktır. Bu temel amaç doğrultusunda yanıt aranan alt sorular şunlardır:

1. Deney ve kontrol grubu katılımcılarının not alma puanları arasında anlamlı fark var midir?

2. Deney ve kontrol grubu katılımcılarının konu alanı başarı puanları arasında anlamlı fark var midir?

3. Katılımcıların not alma puanları ile konu alanı performans puanları arasında nasıl bir ilişki vardır?

4. Öğrenenlerin not alma biçimlerine yönelik görüşleri nelerdir?

\section{Yöntem}

$\mathrm{Bu}$ araştırmada, nitel ve nicel araştırmaların bir arada kullanıldığı karma yöntem kullanılmıştır. Sosyal bilimlerde amaçlı olarak iki ya da daha fazla analiz veya veri toplama yolunun aynı araştırmada kullanılması karma yöntem olarak tanımlanır (Greene ve diğerleri, 2005). Bu yöntemde veri çeşitlemesi yoluna gidildiği için hem nitel hem de nicel verilerin kullanılması araştırmanın güvenilirliğini artırır. Sosyal olguların karmaşık bir yapıya sahip olması farklı yöntemlerin bir araya getirilmesiyle giderilmekte ve çalışmaya daha olumlu katkı getirmektedir (Creswell, 2003:211). Nicel boyut ile daha fazla sayıda katılımcıya ulaş1ırken, nitel boyut ile de araştırma konusunun derinlemesine incelenmesi sağlanır (Greene ve diğerleri, 2005). Bu durumda, araştırmacıya farklı yöntem ve stratejileri birlikte kullanarak veri elde etme olanağ sunulur (Johnson ve Onwuegbuzie, 2004).

Creswell (2003) nicel araştırmalarda verilen hipotezlerin test edilmesi ve elde edilen verilerin sayısal olarak ölçülmesinin esas olduğunu ifade etmiştir. $\mathrm{Bu}$ araştırmanın nicel boyutunda deneysel bir çalışma gerçekleştirilmiştir. Deneysel yöntem, neden-sonuç ilişkilerini tespit etmeye çalışmak amacıyla araştırmacının kontrolü altında, gözlenmek istenen verilerin üretildiği araştırma modelidir (Karasar, 2002:87). Bu yönüyle araştırmalara nesnellik kazandıran nicel araştırmalar sayesinde bazı genellemelere ulaşmak mümkündür. $\mathrm{Bu}$ araştırmada, bir devlet üniversitesinin, eğitim fakültesi, rehberlik ve psikolojik danışmanlık bölümüne devam eden birinci sınıf öğrencilerinin not alma şekillerinin konu alanı performanslarına etkisi incelenmiştir. Deney grubu katılımcılarından, konunun ana hatlarının 
Örgütleyici Yapı İskelesi Tekniğinin Öğretmen Adaylarının Not Alma Becerilerine ve Akademik Başarılarına Etkisi

organize edildiği örgütlenmiş yapı iskelesi tekniği ile hazırlanmış not formlarına not almaları istenilirken, kontrol grubundaki katılımcıların not tutma şekilleri bireysel tercihlerine bırakılmıştır. Her iki gruba da içerik aynı sürede sunulmuştur.

Nicel boyut, araştırmacılara değişkenler arasında karşıllaştırma yapma imkânı sağlamaktadır. Araştırmanın nicel boyutu, deney ve kontrol grubu desenine göre oluşturulmuştur. Bu çerçevede, araştırma ön-test/son-test kontrol gruplu deneme desenine göre modellenmiştir. Modelin simgesel görünümü Şekil 2'de gösterildiği gibidir.

\begin{tabular}{cccc}
\hline Grup & Ön-Test & İşlem & Son-Test \\
\hline $\begin{array}{c}\mathrm{D} \\
\text { Deney }\end{array}$ & K1 & $\mathrm{X}$ & $\mathrm{S} 1$ \\
& Konu alanı performans testi & Yapı iskelesi ile Not Alma & Konu alanı performans testi \\
$\mathrm{K}$ & $\mathrm{O} 2$ & $\mathrm{Y}$ & $\mathrm{S} 2$ \\
Kontrol & Konu alanı performans testi & Serbest Not Alma & Konu alanı performans testi
\end{tabular}

\section{Şekil 2. Deneysel Çalışma Deseni}

Doğal ortamlar, değişkenlerin çok kuvvetli olduğu ortamlardır ve çok yönlü araştırmaların yapılmasına, geniş denencelerin sınanmasına imkân vermektedir (Yazıcığlu ve Erdoğan, 2004:75). Araştırmaların nicel boyutlarında gerçekleşebilme olasıllığı olan hatalar nedeniyle nitel araştırma yöntemlerinden de faydalanmak araştırmalara bütünlük kazandırmaktadır. Creswell (1998:15) nitel araştırmaları, sosyal ve insan kaynaklı problemleri keşfetmek için açıklama temelli bir dizi araştırma geleneklerini içeren araştırmalar olarak tanımlamıştır. Bu tür araştırmalarda, araştırmacılar mevcut durumlara ya da problemlere dair bir akışı oluşturup sunmaya çalışırlar. Süreçte hem araştırmacıların hem de katılımcıların tarafsızlığının sağlanması oldukça önemlidir. Bu araştırmanın nitel boyutunda ise, deney ve kontrol grubundaki toplam 14 katılımcı ile yarı-yapılandırılmış görüşme yapılmıştır.

Yarı yapılandırılmış görüşmelerden elde edilen veriler içerik analizine tabi tutulmuştur. İçerik analizinde, toplanan verilerin kavramalarla ve ilişkilerle açıklanması amaçlanmaktadır. $\mathrm{Bu}$ analizde temelde yapılan işlem, birbirine benzeyen verileri belirli kavramlar ve temalar çerçevesinde bir araya getirmek, düzenlemek ve yorumlamaktır (Yıldırım ve Şimşek, 2005). Bu çalışmada verilerin içerik analizinin yapılması üç aşamada gerçekleşmiştir: İlk aşamada görüşme sorularına verilen yanıtlardan araştırmanın amacına yönelik olarak ortaya çıkan ana temalar belirlenmiştir. İkinci aşamada, veriler belirlenen ana temalara göre okunarak organize edilmiş ve ana temaların alt temaları belirlenmiştir. Son aşamada ana tema ve alt temalara göre veriler tanımlanmış ve gerekli alıntılarla ortaya çıkan bilgiler birbirleri ile ilişkilendirilerek sunulmuştur.

Tashakkori ve Creswell (2013) karma yöntem kullanılan araştırmaların, araştırma sorularının nitel ve nicel boyutlarını açıkça ortaya koymaları gerektiğini, nitel ve nicel analizlerden elde edilen verileri net bir şekilde belirtmeleri gerektiğini, uygun nitel ve nicel veri analizlerinin sonuçlarından açık sonuçlar ortaya koymaları gerektiğini ve tek başına nitel veya nicel boyuttan daha bütünleşmiş sonuçlar vermeleri gerektiğini belirtmişlerdir. Karma yöntemin 
kullanıldığı araştırmalarda bir konunun veya olgunun hem nitel hem de nicel boyutlar kullanılarak farklı açılardan derinlemesine incelenmesi araştırmalara güç katar. Creswell (2003), bu tür araştırmalarda kullanılan stratejileri, yerleştirme / uygulama (implementation), öncelik (priority), birleştirme (integration), teorik bakış açısı (theoretical perspective) şeklinde sıralamıştır. Bu araştırmada "yerleştirme / uygulama" stratejisi kullanılmıştır. Bu tür araştırmalarda, nicel ve nitel uygulamalar araştırmanın kapsamına bağlı olarak sırayla veya aynı zamanda yapılarak veriler elde edilir. Bu araştırmada öncelikle deneysel desen uygulanmış daha sonrasında ise yarı-yapılandırılmış görüşmeler yapılmıştır.

\section{Çalışma Grubu}

Araştırmada deneysel desen kullanıldığından ayrıca bir evren tayinine gidilmemiştir. Araştırmanın çalışma grubunu, bir devlet üniversitesinin eğitim fakültesindeki rehberlik ve psikolojik danışmanlık bölümüne devam eden birinci sınıf öğrencileri oluşturmuş̧tur. Deney grubunda 21 kadın 9 erkek olmak üzere 30, kontrol grubunda da 19 kadın 11 erkek olmak üzere 30 gönüllü öğrenci çalışma grubunda yer almıştır. Deney ve kontrol grupları oluşturulurken katılımcıların ilgili bölüme yerleşme puanları ile ön-test puanları göz önünde bulundurulmuştur.

Tablo 1. Deney ve Kontrol Grubu Öğrencilerinin Not Alma Ön-test Puanları Arasındaki Farka Ait t-testi sonuçları

\begin{tabular}{ccccccc}
\hline Gruplar & $\mathbf{n}$ & $\bar{X}$ & ss & sd & t & p \\
\cline { 1 - 4 } Deney & 30 & 8.83 & 12.29 & 2.24 & \multirow{2}{*}{.105} & .916 \\
\cline { 1 - 5 } Kontrol & 30 & 8.50 & 12.18 & 2.22 & & \\
\hline
\end{tabular}

Tablo 1'de görüldüğü gibi deney ve kontrol grubu öğrencilerinin ön-test puanları arasında anlamlı bir fark gözlenmemiştir ( $>$ >.05). Bu durum grupların homojen bir yapıya sahip olduğunu göstermektedir.

Araştırmanın nitel boyutunda deney grubundan 7 ve kontrol grubundan 7 olmak üzere rastgele seçilmiş olan toplam 14 istekli öğrenci ile yarı yapılandırılmış görüşme yapılmış ve not alma biçimlerine ilişkin sorular yöneltilmiştir.

\section{Verilerin Toplanması ve Çözümlenmesi}

Çalışmanın temel amacına ve alt problemlerine ilişkin üç veri toplama aracı kullanılmışıtır. Bunlardan birincisi öğrencilerin not alma formları, ikincisi konu alanı performans testi ve sonuncusu da yarı-yapılandırılmış görüşme formudur. Araştırmanın amacı doğrultusunda, öğrencilerin not alma biçimleri ile konu alanı performansları arasındaki ilişkiyi saptamak amacıyla alanyazında yer alan çalışmalardan yararlanarak örgütleyici yapı iskelesi not alma formları hazırlanmış; kapsam geçerliği ve anlaşılabilirliğini değerlendirmek için eğitim bilimleri alanından 1, Türkçe eğitimi alanından 2 olmak üzere 3 alan uzmanının görüşleri alınmıştır. Uzmanlardan gelen geribildirimler doğrultusunda yapı iskelesi not alma formlarına son biçimi verilmiştir. Veri toplama sürecinde öncelikle öğrencilere "Freud ve Kuramları" sözlü sunum yoluyla anlatılmış, kontrol grubu öğrencilerinden konuyu dinlerken serbest biçimde not almaları istenmiştir. Deney grubu öğrencilerine ise örgütleyici yap1 iskelesi tekniği kullanılarak hazırlanan not alma formları verilmiş ve derste edindikleri bilgilerle bu formları tamamlayabilecekleri söylenmiştir. Öğrenciler tüm bu işlemleri tamamladıktan sonra her iki grubun not aldıkları formlar not alma değerlendirme rubriği ile değerlendirilmiştir. Bu rubrik 
Örgütleyici Yapı İskelesi Tekniğinin Öğretmen Adaylarının Not Alma Becerilerine ve Akademik Başarılarına Etkisi

hazırlanırken öncelikle Chaudron, Loschky ve Cook (1994:81) tarafindan ortaya konulan bazı ölçütler göz önünde bulundurulmuş ve üç uzmandan alınan görüşler doğrultusunda son hali verilmiştir. Sözü edilen ölçütler Şekil 3’te yer almaktadır:

\begin{tabular}{ll}
\hline Nicelik & Toplam sözcük \\
\cline { 2 - 2 } & Toplam bilgi öbeği \\
\hline \multirow{3}{*}{ Nitelik } & $\begin{array}{l}\text { Yeterlilik ve yoğunluk (Bilgi öbeğinin ya da düşüncelerin toplam sözcüğe oranı, } \\
\text { kelimesi kelimesine mi yoksa öz veya kısaltma yapılmış biçimde mi?) }\end{array}$ \\
\cline { 2 - 2 } & $\begin{array}{l}\text { Eksiksizlik (Alınan nottaki toplam bilgi öbeği ya da düşüncenin, metindeki toplam } \\
\text { bilgi öbeği ya da düşüncelere oranı) }\end{array}$ \\
\cline { 2 - 2 } & Soruları yanıtlayabilirliği (Soru maddeleriyle ilgili bilgi öbeği veya düşünce sayısı) \\
\cline { 2 - 2 } & Bilgi düzeyi (Metindeki alt düzey bilgiyle ilişkili üst düzey bilgi oranı ve sayısı) \\
\hline & $\begin{array}{l}\text { Organizasyon özellikleri (ana hat, çizimler, simgeler, numaralandırma, örnek } \\
\text { gösterimi, başlıklar). }\end{array}$ \\
\hline
\end{tabular}

\section{Şekil 3. Not-Alma Formları Değerlendirme Rubriği Kriterleri}

Hazırlanan rubrik iki değerlendirmeci tarafından kullanılarak not kâğıtları değerlendirilmiş ve her ikisinin verdiği puanların ortalaması öğrencilerin not alma puanlarını ortaya koymuştur. Puanlayıcılar arasında .74 korelasyon bulunması yapılan değerlendirmede 0.01 düzeyinde kabul edilir bir ilişkinin olduğunu ortaya koymaktadır.

Hem deney hem de kontrol grubunda Eğitim psikolojisi dersinde "Freud \& Kuramları" 3 hafta süre ile işlenmiştir. Konunun kazanımlarına ilişkin bir belirtke tablosu hazırlanarak kapsam geçerliliği güvence altına alınmıştır. Bu doğrultuda hazırlanan konu alanı performans testinde ölçme değerlendirme güvenirliği açısından soru çeşitliliğine gidilmiştir. Sorular, kazanımlara hizmet etme durumlarına göre 5 ile 10 puan şeklinde puanlanmıştır. Konu alanı performans testinde toplamda 15 soru vardır ve hazırlanan taslak teste ilişkin alan uzmanlarının görüşü alınmıştır. Test, konu alanının yapısıyla ilişkili olarak farklı zihinsel basamaklardan sorular içermektedir. Araştırmanın son aşamasında da uygulanan konu alanı performans testinin Cronbach Alfa güvenirlik katsayıs1 .83'tür.

Araştırmanın deney aşamasında yansızlığı sağlamak amacıyla veriler araştırmacılar tarafından toplanıp değerlendirilmiştir. Ön-test sorularından elde edilen puanlar gruplar oluşturulduktan sonra yansızlığı test etmek amacıyla kullanılmıştır. Araştırmanın nicel boyutundan elde edilen veriler istatistik paket programı kullanılarak analiz edilmiştir. Analizler için önce tüm puanlar standart puanlara dönüştürülmüştür. Normal dağılım için verilerin basıklık (curtosis) ve çarpıklık (skewness) değerleri incelenmiştir. Elde edilen bu sonuçlar ile verilerin normal bir dağılım gösterdiği söylenebilir.

Deney ve kontrol grubu katılımcılarının not alma puanları arasında anlamlı fark olup olmadığına bağımsız gruplar t-testi ile bakılmıştır. Sonrasında deney ve kontrol grubu katılımcılarının not alma puanları arasında anlamlı bir fark bulunduğundan not alma puanları kontrol altına alınarak, deney ve kontrol grubu katılımcılarının konu alanı performans testi puanları arasında anlamlı fark olup olmadığına ise kovaryans analizi (ANCOVA) ile bakılmıştır. Kovaryans analizinde bağımlı değişkenden, ortak değişkenden kaynaklı değişmeleri çekip çıkarmak ve sonra da bağımlı değişkendeki değişmenin bağımsız değişkenden kaynaklanıp kaynaklanmadığını anlamak amacıyla gerçekleştirilir. Kovaryans analizdeki bir değişkeni denetlemek yani, kontrol etmek için kullanılan yollardan en genelidir (Punch, 2005). Bu araştırmada, grupların not tutma puanları arasında anlamlı bir fark bulunduğundan bu puanların 
olası etkisini ortadan kaldırmak için ANCOVA uygulanmıştır. Grupların not alma puanları ile konu alanı performans testinden elde edilen puanların arasında bir ilişki olup olmadığını daha net belirlemek için serpilme grafiği yapılmış ve korelasyon katsayıları hesaplanmıştır.

Öğrenenlerin not alma biçimlerine yönelik görüşlerinin alınması araştırmanın nitel boyutunu ortaya koymaktadır. Yarı yapılandırılmış görüşme formuyla araştırmanın amacı doğrultusunda deney grubuna " Örgütleyici yap1 iskelesi tekniğinin not alma sürecine etkisi nedir?" öte yandan kontrol grubuna da "Serbest not almanın not alma sürecine etkisi nedir?" sorusu yöneltilmiştir. Açık uçlu yapılandırılmış sorular katılımcılara verdikleri yanıtların nedenlerini de dile getirme olanağı tanır ve onların bu kavramlarla ilgili düşünme durumlarını yansıtır. Toplanan veriler iki ayrı araştırmacı tarafından bağımsız olarak çözümlenmiştir. Araştırmacıların bağımsız biçimde yaptıkları kodlamaların uyum derecesi "Güvenirlik =(Uyuşum kategorilerinin sayısı) (Uyuşan ve uyuşmayan kategorilerin toplam sayısı)" formülü ile hesaplanmıştır (Miles ve Huberman, 1994; akt., Köğce, 2017). Hesaplama sonucunda araştırmacılar arası uyuma yönelik güvenirlik derecesi deney grubu için 0,86 , kontrol grbu verileri için 0,88 olarak bulunmuştur. Buna göre kodlayıcılar arası tutarlığın güvenilir olduğuna karar verilmiştir. Uyum olmayan bölüm tartışılarak ortak karar alınmış ve kodlanmıştır.

\section{Bulgular}

\section{Nicel Bulgular}

Araştırmanın birinci sorusu doğrultusunda, deney ve kontrol gruplarının not alma puanları arasında fark olup olmadığını ortaya koymak için bağımsız gruplar t-testi yapılmış ve sonuçlar Tablo 2'de verilmiştir.

Tablo 2. Deney ve Kontrol Grubu Öğrencilerinin Not Alma Puanları Arasındaki Farka Ait t-testi Sonuçları

\begin{tabular}{ccccccc}
\hline Gruplar & $\mathbf{n}$ & $\bar{X}$ & ss & sd & t & p \\
\hline Deney & 30 & 6.7 & 1.48 & .27 & \multirow{2}{*}{.5 .89} & .000 \\
\cline { 1 - 5 } Kontrol & 30 & 4.16 & 1.82 & .33 & & \\
\hline
\end{tabular}

Tablo 2'de görüldüğü gibi deney ve kontrol gruplarının not alma puanları arasında yapılan bağımsız gruplar t-testi sonuçları iki grubun not alma puanları arasında anlamlı bir fark olduğunu ortaya koymuştur. Deney grubunun not alma puanı ortalaması (6.7), kontrol grubu not alma puanı ortalamasından (4.16) daha yüksektir.

Araştırmanın ikinci sorusuna ilişkin olarak, deney ve kontrol grubu katılımcılarının konu alanı performans testi puanları arasında anlamlı bir fark olup olmadı̆̆ını ortaya koymak için kovaryans analizi uygulanmıştır. Bu analizden elde edilen deney ve kontrol grubunun düzeltilmiş not ortalamaları Tablo 3'te verilmiştir. 
Örgütleyici Yapı İskelesi Tekniğinin Öğretmen Adaylarının Not Alma Becerilerine ve Akademik Başarılarına Etkisi

Tablo 3. Grupların Ortalamaları ve Düzeltilmiş Ortalamaları

\begin{tabular}{cccc}
\hline Grup & N & Ortalama & Düzeltilmiş Ortalama \\
\hline Deney & 30 & 73.83 & 68.73 \\
Kontrol & 30 & 46.83 & 51.92 \\
\hline
\end{tabular}

Deney ve kontrol grubu katılımcılarının konu alanı performans testi puanları düzeltilmiş ortalamaları sırasıyla 68.73 ve 51.92 şeklindedir. Deney ve kontrol grubu öğrencilerinin son-test performans puanlarındaki farka ilişkin anlamlılık bulguları Tablo 4'te verilmiştir.

Tablo 4. Deney ve Kontrol Grubu Öğrencilerinin Son-test Başarı Puanları Arasındaki Farka Ait ANCOVA Sonuçları

\begin{tabular}{ccccc}
\hline $\begin{array}{c}\text { Varyansın } \\
\text { Kaynağı }\end{array}$ & $\begin{array}{c}\text { Kareler } \\
\text { Toplamı }\end{array}$ & $\begin{array}{c}\text { Kareler } \\
\text { Ortalaması }\end{array}$ & F & $\begin{array}{c}\text { Anlamlılık } \\
\text { Düzeyi }\end{array}$ \\
\hline Not Alma & 2595.275 & 2595.275 & 16.057 & .000 \\
Gruplar & 2649.899 & 2649.899 & 16.395 & .000 \\
\hline
\end{tabular}

Etki Büyüklüğ̈̈ $(r=.481)$

Grupların ANCOVA sonuçları dikkate alınarak hazırlanan Tablo 4'te deney ve kontrol gruplarının son-test performans puanları arasında anlamlı bir fark olduğu ve grupların not alma puanları kontrol altına alındığında grup ortalamalarında değişmeler olduğu görülmektedir. Gruplar arasındaki farkın anlamlı olduğu yine Tablo 3’te de açıkça görülmektedir.

Araştırmanın üçüncü sorusuyla bağlantılı olarak deney ve kontrol grubunun son-test puanları arasındaki farkın not alma biçimlerinden kaynaklanabileceği düşüncesi ile her iki grubun da not alma puanları ile konu alanı performans puanları arasında ilişki olup olmadığına Pearson korelasyon katsayısı hesaplanarak bakılmıştır. Söz konusu katsayı, iki sürekli değişkenin doğrusal ilişkisinin derecesinin ölçümünde kullanılır. Bu bağlamda, deney ve kontrol grubu öğrencilerinin not alma biçimleri ile performansları arasında anlamlı bir ilişki var mıdır sorusunun yanıtını almak amaciyla korelasyon katsayısı hesaplanmadan önce serpilme grafiği yapılarak doğrusal ilişki olup olmadığı kontrol edilmiştir. Gruplara ait serpilme grafikleri Şekil 4 ve 5 'te verilmiştir.

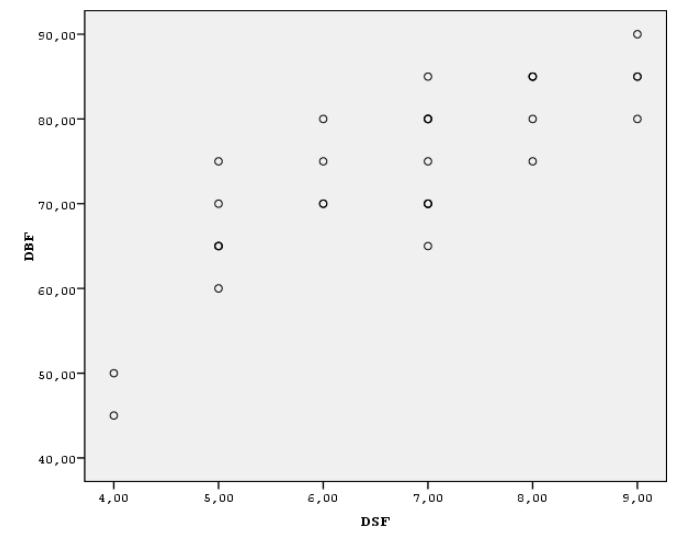

Şekil 4. Deney Grubu Yapı İskelesi Not Alma Puanları ile Konu Alanı Performans İlişkisi Serpilme Grafiği 
Şekil 4'te görüldüğü gibi deney grubuna ait serpilme grafiği incelendiğinde deney grubunun not alma ve performans puanları arasında pozitif yönde bir ilişki olduğundan bahsetmek olasıdır. Kontrol grubunun not alma puanları ile konu alanı performans puanları arasındaki ilişkiye ait serpilme grafiği şekil 5 'te verilmiştir.

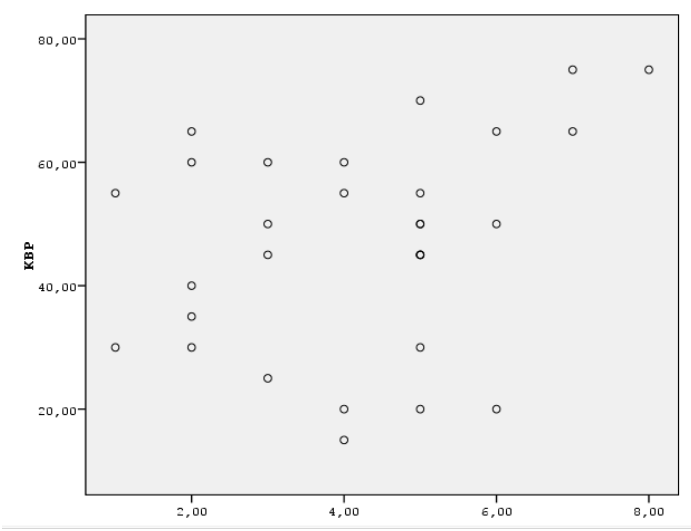

\section{Şekil 5. Kontrol Grubu Not Alma Puanları ile Konu Alanı Performans İlişskisi Serpilme Grafiği}

Şekil 5'te görüldügü gibi kontrol grubunun not alma ve konu alanı performans puanları arasında herhangi bir korelasyondan söz etmek mümkün değildir.

Deney grubunun not alma puanları ile konu alanı performansları arasında ilişkinin desteklenmesi açısından Pearson korelasyon katsayısı hesaplanmış ve bulgular Tablo 5 'te verilmiştir.

Tablo 5. Deney Grubu Korelasyon Analizi Sonuçları

\begin{tabular}{cccc}
\hline & & DGNP & DGPP \\
\hline Deney Grubu Not Alma Puanları & Pearson Korelasyon & 1 & .821 \\
& $\mathrm{r}$ & & .000 \\
\cline { 2 - 4 } Deney Grubu Performans Puanlar1 & Pearson Korelasyon & .821 & 1 \\
& $\mathrm{r}$ & .000 & \\
\hline
\end{tabular}

Tablo 5'e göre, deney grubunun not alma puanları ile performans puanları arasında oldukça kuvvetli, pozitif yönde ve anlamlı bir ilişki olduğu anlaşılmaktadır. Korelasyon katsayısı $(r=.821)$ olarak hesaplanmıştır. Buna göre, deney grubu öğrencilerinin not alma puanı arttıkça performans puanının arttığı söylenebilir.

\section{Nitel Bulgular}

Araştırmanın dördüncü sorusu ile bağlantılı olarak deney ve kontrol grubu katılımcılarının not alma biçimlerine yönelik görüşlerinin ortaya konması amaçlanmıştır. Araştırmada deney ve kontrol gruplarından 14 öğrenci ile yarı-yapılandırılmış görüşme yapılmış ve bu görüşmelerden elde edilen veriler çözümlenerek temalar oluşturulmuştur. Yedi deney grubu öğrencisinin örgütleyici yapı iskelesi not alma tekniğinin not alma sürecine etkisine ilişkin görüşleri alınmış ve bulgular Tablo 6'da verilmiştir. 
Örgütleyici Yapı İskelesi Tekniğinin Öğretmen Adaylarının Not Alma Becerilerine ve Akademik Başarılarına Etkisi

Tablo 6. Deney Grubu Yarı-Yapılandırılmış Görüşme Bulguları

\begin{tabular}{lcc}
\hline Temalar & $\mathbf{n}$ & $\mathbf{\%}$ \\
\hline Konunun bütününe hakim olabilme & 5 & 72 \\
\hline Ön bilgilerle ilişsilendirebilme & 5 & 72 \\
\hline Öğretim elemanının hızına uyum sağlayabilme & 7 & 100 \\
\hline Daha anlaşılır ve rasyonel not tutabilme & 6 & 86 \\
\hline Odaklanmayı sağlama & 6 & 86 \\
\hline Kalıcılığın desteklenmesi & 5 & 72 \\
\hline
\end{tabular}

Örgütleyici yap1 iskelesi tekniği kullanılarak not almaları sağlanan deney grubu öğrencilerine ait bulgular Tablo 6'da görülmektedir. Öğrenciler dağıtılan not formları sayesinde konunun bütününe hakim olabildiklerini (\%72), not kağıdındaki bilgilerle daha öncesinde edindikleri bilgileri ilişkilendirebildiklerini (\%72) ifade etmişlerdir. Öğrenciler örgütleyici yapı iskelesi tekniğine göre hazırlanmış not alma formlarında içeriğe ilişkin bazı önemli noktalar hazır verildiğinden öğretim elemanının anlatım hızına uyum sağlayabilmekte (\%100) ve daha düzenli not alabilmektedirler (\%86). Ayrıca öğrenciler derse daha iyi odaklandıklarını (\%86) ve sonrasında aldıkları notlardaki şekilleri veya imgeleri daha iyi hatırlayabildiklerini $(\% 72)$ ifade etmişlerdir.

Yedi kontrol grubu öğrencisi ile serbest not almanın not alma sürecine etkisi konusunda görüşülmüş ve ortaya çıkan temalara ait frekanslar Tablo 7'de verilmiştir.

Tablo 7. Kontrol Grubu Yarı-Yapılandırılmış Görüşme Bulguları

\begin{tabular}{lcc}
\hline Temalar & $\mathbf{n}$ & $\mathbf{\%}$ \\
\hline Yeterince hızlı yazamama & 6 & 86 \\
\hline Öğretim elemanının anlatım hızına yetişme & 5 & 72 \\
\hline Hangi bilginin önemli olduğuna karar verememe & 6 & 86 \\
\hline Organizasyonun sağlanamaması & 4 & 58 \\
\hline Bazı noktaları kaçırma ve hatırlayamama & 7 & 100 \\
\hline Daha sonra üzerinden geçmenin zorluğu & 5 & 72 \\
\hline
\end{tabular}

Tablo 7'de görüldüğü gibi kontrol grubu öğrencileri not alma sürecinde yeterince hızlı yazmakta (\%86), öğretim elemanının anlatım hızına yetişmekte $(\% 72)$ sorun yaşadıklarını dile getirmişlerdir. Bunun yanı sıra konuya ilişkin ön bilgileri yeterli olmadığı durumlarda hangi bilginin daha önemli olduğunu ayırt edemediklerinden (\%86), notlarının düzenini sağlayamadıklarından (\%58) söz etmişlerdir. Ayrıca öğrenciler, not alma sürecinde kaçırdıkları bilgileri daha sonra hatırlayamadıklarını (\%100) ve ders sonrasında da notların tekrar üzerinden geçilmesinin zor olduğunu (\%72) ifade etmişlerdir.

\section{Tartışma ve Sonuç}

$\mathrm{Bu}$ çalışmada, ipucu olarak örgütleyici yapı iskelesi kullanımının öğrencilerin not alma becerileri üzerinde etkisi olup olmadığını ortaya koymak amaçlanmıştır. Deney grubu katılımcılarından, konunun ana hatlarının organize edildiği yapı iskelesi tekniği ile hazırlanmış not kâğıtlarına not almaları istenilirken, kontrol grubundaki katılımcıların not alma biçimleri bireysel tercihlerine bırakılmıştır. Yapılan uygulama sonucu ortaya çıan ürünler değerlendirilerek öğrencilerin not alma performansları araştırmacılar tarafından geliştirilen rubrik ile değerlendirilmiştir. Yapılan çözümleme sonucunda deney ve kontrol grubu katılımcılarının not alma puanları arasında anlamlı fark olduğu saptanmıştır. Deney grubu 
katılımcilarının not alma puanı ortalaması kontrol grubu kat1lımcılarının not alma puanı ortalamasından daha yüksek bulunmuştur. Castello ve Monero'nun (2005) çalışmasının sonuçlarında, üniversite öğrencilerinin not alma yöntemlerinin birçoğunu bilmedikleri ve not alma becerilerinin zayıf olduğu belirtilmektedir. İncelendiğinde birçok çalışmanın sonuçlarında benzer durumlara rastlanmıştır (Jairem \& Kiewra, 2009; Boyle ve Forchelli, 2014; Ilter, 2017).

Çalışmanın ikinci sorusu doğrultusunda, deney ve kontrol grubu katılımcılarının konu alanı başarı puanları arasında anlamlı bir fark olup olmadığını belirlemeye dönük çözümlemeler sonucunda not alma biçimleri kontrol altına alındığında grup ortalamalarında değişmeler olduğu ve gruplar arasındaki farkın anlamlı olduğu görülmüştür. Her iki grubun düzeltilmiş ortalamaları arasındaki fark 26,8 olarak bulunmuştur. Bu çalışmadaki deneysel işlemin sonuçları, konunun ana hatlarının organize edildiği örgütleyici yapı iskelesi tekniği ile hazırlanmış not kâğıtlarının öğrencilerin nitelikli not alabilmeleri, derse odaklanmaları konusunda etkili bir yöntem olduğunu göstermiştir. Etkili not almak için kişi önce dinlemeli ve öğretim elemanının söylediği bilgiyi kavramalıdır. İnsanlar aynı anda çevredeki her şeye etkin bir şekilde katılmayı başaramadıklarından bu öğrencinin dikkatini (odak etmeni/focus factor) eğitmenine yönlendirmesini gerektirir. Not alanın not alırken dikkat kaynaklarının bir kısmını yazma eylemine aktarması ve dinleme/yazma arasında sürekli geçiş yapması gerekir (değiştirim etmeni/shift factor). Eksiksiz notlar alabilmek için, odak dersin bütününde kesintisiz olarak sürdürülmelidir (sürdürme ve kararlılık etmenleri/sustain and stability factors). Böylece not alan önemli şeyleri kaçırmaz (Gleason, 2012:28).

Alanyazında yer alan çalışmaların sonuçları, not alan öğrencilerin notlarını gözden geçirmeseler bile not almayanlara oranla konu alanı testinden daha başarılı olabildiklerini göstermektedir. Fakat not almak karmaşık ve zor bir süreç olduğundan, öğrenciler kimi zaman not alma uğraşı esnasında dinleme edimini sürdürmekte ve dikkatini öğretmenin anlattıklarına vermekte zorlanmaktadır. Bu yüzden de önemli noktaları kaçırabilmektedir. Serbest not alma yöntemi kullanan kontrol grubu katılımcılarının not alma puanları ile konu alanı puanları arasında anlamlı bir korelasyon bulunmamıştır. Öte yandan, deney grubunun not alma puanları ile konu alanı puanları arasında oldukça kuvvetli, pozitif yönde ve anlamlı bir ilişki olduğu saptanmıştır. Buna göre, deney grubu öğrencilerinin not alma puanı arttıkça konu alanı performans puanının arttığı söylenebilir. Serbest not alma tekniğiyle not alan kontrol grubu katılımcılarının öğretim elemanının anlattığı bazı konuları dinleyebilme olanağı bulamadığ anlaşılmaktadır. Kontrol grubunda yer alan yedi katılımcının yarı yapılandırılmış görüşmede bazı noktaları kaçırdığını ve hatırlayamadığını belirtmesi bu görüşü güçlendirmektedir. Ayrıca elde edilen bulgular, notların organizasyonunu sağlama çabasının kontrol grubundaki katılımcıların öğretim elemanını dinlemeyi sürdürmesini engellediğini göstermiştir.

Alanyazındaki çalışmaların sonuçları alınan notların niteliği ile öğrenme performansı arasındaki ilişkiyi güçlü bir biçimde ortaya koymaktadır. Bazı çalışmalarda, Cornell, tümleşik not alma sistemi (unified note-taking system), bölünmüş sayfa yöntemi (split page method) gibi çeşitli yöntemler kullanarak ve not alma stratejileri eğitimi vererek öğrencilerin not alma becerilerini olumlu yönde geliştirmeye çalışıldığı görülmektedir (Austin, Lee, Thibeault, Carr ve Bailey, 2002; Quintus, vd., 2012; Chandler, 2017; Petty, Sykes ve Dugger, 2017; Pardini, Domizi, Forbes ve Pettis,2005;Robinson, 2018 ). Tüm bu çalışmalar diğer okuma, yazma gibi dilsel beceri alanlarına benzer olarak not alma sürecinde de belli stratejilerin kullanımının 
Örgütleyici Yapı İskelesi Tekniğinin Öğretmen Adaylarının Not Alma Becerilerine ve Akademik Başarılarına Etkisi

gerekliliğine vurgu yapar. Öğrenciler eğitim öğretim süreci boyunca doğrudan not almaya dönük bir eğitim almadıklarından ve sürece ilişkin stratejiler geliştiremediklerinden not alma becerilerinde gelişim sağlayamamaktadır. Ayrıca, öğrencilerin kendi notlarını gözden geçirmesi başkalarının aldığı notları gözden geçirmesinden daha etkilidir. Çünkü üretken öğrenme modeline (generative model of learning) göre öğrenenler artalan bilgileriyle uyumlu anlamlar ve algılar (perceptions) üretirler (Witrock, 1989). Kavrayarak öğrenme kişinin artalanı, tutumları, becerileri ve deneyimlerine uygun anlamı üretme ve aktarma sürecini içerir. Anlamlı öğrenme, üretim (generation), güdü, dikkat ve bellek (memory) olmak üzere dört temel bileşenden oluşur. Üretim, öğrenenin öğrenilmesi gereken materyalin farklı ögeleri (iç bağlantılar), öğrenilmesi gereken materyaller ve öğrenenin var olan bilgisi (dışsal bağlantılar) arasında kurduğu bağlantılardır. Güdü, öğrencinin materyali anlamaya yönelik çaba gösterme isteğidir. Dikkat, üretken süreçleri yeni gelen materyale ve depolanan bilgiye yöneltmektir. Bellek öğrencinin ön bilgisi, deneyimleri ve inançları ile ilgilidir. Öğrenme üretken bir etkinliktir. Üretken öğrenme ise gelen bilginin kullanılabilir duruma getirilmesidir (Fiorella \& Mayer, 2016).

Yar1 yapılandırılmış görüşme formuyla elde edilen verilerin çözümlenmesiyle ortaya çıkan bulgular deney ve kontrol gruplarının son-test puanları arasındaki farkın kaynağını açıkça ortaya koymuş̧tur. Buna göre, konunun ana hatlarının organize edildiği yapı iskelesi tekniği ile hazırlanmış not kağıtları öğrencilerin önemli noktaları fark etmelerini, bilgiyi rahatlıkla organize etmelerini ve daha önceden anlatılanlarla sonraki bilgiler arasında ilişki kurabilmelerini ve öğretim elemanının anlatımına daha iyi odaklanmalarını sağlamıştır. Öte yandan, kontrol grubunda yer alan katılımcıların aldıkları notların zayıflığının temelinde ise yeterince hızlı yazamamaları, öğretim elemanının anlatım hızına yetişememeleri, önemli bilgiye karar vermede zorlanmaları ve notlarını organize edememeleri gibi nedenler yer almaktadır.

Sonuç olarak, öğrenmenin ve öğrenilen bilgilerin kalıcılığının sağlanmasında not alma önemli bir stratejidir. Fakat, gerek bu çalışmanın sonuçları gerekse alan yazında yer alan birçok çalışmanın sonuçlarından öğrencilerin not alma becerilerinin zayıf olduğu anlaşılmaktadır. $\mathrm{Bu}$ nedenle, öğretmenlerin öğrencilerin nitelikli not alabilmesini sağlamak için çeşitli yöntemler kullanması bir gerekliliktir. $\mathrm{Bu}$ çalışmada uygulanan örgütleyici yap1 iskelesi tekniğinin öğrencilerin nitelikli not alması konusunda etkili olduğu görülmüştür. Bunun yanında dinlediğini anlama ve hatırlama konusunda da etkili bir yöntem olduğu görülmüştür. Cornell, tümleşik not alma sistemi ve bölünmüş sayfa yöntemi gibi diğer not alma yöntemleriyle örgütleyici yap1 iskelesi yönteminin not alma becerisine etkisi konusunda karşılaştırmalı çalışmalar yapılabilir. Öğrencilerin tüm bu yöntemlere ilişkin tercihleri ve tercih nedenlerine ilişkin yapılacak çalışmaların sonuçları ders aracı hazırlayanlara, konu sunumu yapan öğretmenlere ve araştırmacılara önemli veriler sağlayabilir. 


\section{Kaynakça}

Amiripour, P., Amir-Mofidi, S. \& Shahvaran, A. (2012). Scaffolding as effective method for mathematical learning. Indian Journal of Science and Technology, 5(9), 3328-3331.

Arı, Ü. (2017). Yapı iskelesi desteğiyle sorgulamaya dayalı öğretim yönteminin uygulamadaki etkisinin araştırılması. (Yayımlanmamış doktora tezi). Fırat Üniversitesi/Eğitim Bilimleri Enstitüsü, Elazığ.

Austin, J. L., Lee, M. G., Thibeault, M. D., Carr, J. E., \& Bailey, J. S. (2002). Effects of guided notes on university students' responding and recall of information. Journal of Behavioral Education, 11, 243254.

Baki, A. (2008). Kuramdan uygulamaya matematik ĕgitimi. Ankara: Harf Eğitim Yayıncılığı.

Barak, R. \& Carla, M. (1992). The use of scaffolds for teaching higher-level cognitive strategies. Educational Leadership, 49(7), 26-33.

Boch, F. \& Piolat, A. (2005). Note taking and learning: A summary of research. The WAC Journal, 16, 101-113.

Bonner, J.M. \& Holliday, W.G. (2006). How college science students engage in note-taking strategies. Journal of Research in Science Teaching, 43 (8), 786-818.

Boyle, J. R. ve Forchelli, G. A. (2014). Differences in the note-taking skills of students with high achievement, average achievement, and learning disabilities. Learning and Individual Differences, 35(2014), 9-14.

Bransford, J., Brown, A., \& Cocking, R. (2000). How people learn: Brain, mind, and experience \& school. Washington, DC: National Academy Press.

Castello, M \& Monereo. C. (2005). Students' note-taking as a knowledge construction tool. Educational Studies in Language and Literature, 5, 265-285.

Chandler, C. (2017). Improving student note-taking skills. The Education Diges, 82(7), 54-56.

Chaudron, C., Loschky, L., and Cook, J. (1994). Second language listening comprehension and lecture note taking. In J. Flowerdew (Ed.), Academic listening: research perspectives. Cambridge: Cambridge University Press.

Chen PH. (2013). The effects of college students' in-class and after-class lecture note taking on academic performance. Asia-Pacific Edu Res. 22(2):173-180.

Creswell, J. W. (1998). Qualitative and inquiry and research design choosing among five traditions. Thousand Oaks: Sage Publications.

Creswell, J. W. (2003). Research design qualitative and quantative and mixed methods approaches. Thousand Oaks: Sage Publications.

Çetingöz, D. (2006). Not alma stratejisinin öğretimi tarih başarısı, hatırda tutma ve başarl güdüsü. Yayımlanmamış Doktora Tezi. Dokuz Eylül Üniversitesi Eğitim Bilimleri Enstitüsü.

DeZure, D., Kaplan, M, \& Deerman, M.A. (2001). Research on student notetaking: Implications for faculty and graduate student instructors. CRLT Occasional Paper No. 16. University of Michigan.

Di Vesta, F. J., \& Gray, G. S. (1972). Listening and note taking. Journal of Educational Psychology, 63(1), 8-14. Retrieved from http://dx.doi.org/10.1037/h0032243

Dickson, S. V., Chard, D. J. \& Simmons, D. C. (1993). An integrated reading/writing curriculum: A focus on scaffolding. LD Forum, 18(4), 12-16.

Durukan, E. ve Maden, S. (2010). Kavram haritaları ile not tutmanın ilköğretim öğrencilerinin dinlediğini anlama becerisi üzerine etkisi. ODÜ Sosyal Bilimler Enstitüsü Sosyal Bilimler Araştırmaları Dergisi, 1(2), 63-70.

Fiorella, L., \& Mayer, R. E. (2016). Eight ways to promote generative learning. Educational Psychology Review, 28(4), 717-741. 
Örgütleyici Yapı İskelesi Tekniğinin Öğretmen Adaylarının Not Alma Becerilerine ve Akademik Başarılarına Etkisi

Friedman, M. C. (2017). Notes on note-taking: Review of research and insights for students and instructors. Harvard Initiative for Learning and Teaching, http://hilt. harvard. edu/files/hilt/files/notetaking_0. pdf. Mihaly Csikszentmihalyi. Flow: The Psychology of Optimal Experience. New York.

Gleason, J. (2012). An investigation of lecture note-taking skills of adolescents with and without Attention Deficit/Hyperactive Disorder: An extension of previous research. (Doctoral dissertation). Columbia University, United States.

Greene, J. C., Krayder, H., \& Mayer, E. (2005). Combining qualitative and quantitative methods in social inquiry. In B. Somekh \& C. Lewin (Eds.). Research Methods in the Social Sciences (p. 275-282). London: Sage Publishing.

$\mathrm{Hu}$, D. (2006). The effects of scaffolding on the performance of students in Computer-based concept linking and retention of comprehension. \{Unpublished Ph.D. thesis in Curriculum and Instruction, (Instructional Design and Technology)\}, Virginia Polytechnic Institute and State University, Blacksburg, Virginia

Ilter, I. (2017). Note taking skills instruction for development of middle school students' note taking performance. Psychology in the Schools, 54(6), 596-611.

Jacqueline D. E. \& Ben K. (2015). Strategies and perceptions of students' field notetaking skills: Insights from a geothermal field lesson. Journal of Geoscience Education,63, 233-249.

Jairam, D. \& Kiewra, K. A. (2009). An investigation of the SOAR study method. Journal of Advanced Academies, 20(4), 602-629.

Johnson, R. B. \& Onwuegbuzie, A. J. (2004). Mixed methods research: A research paradigm whose time has come. Educational Researcher, 33(7), 14-26.

Karasar, N. (2002). Bilimsel araştırma yöntemi. Ankara: Nobel Yayın Dağıtım.

Khosravi, S. K. (2017). The effect of symmetrical scaffolding on the reading comprehension of Iranian EFL learners. International Journal of Psychological and Brain Sciences, 2(4), 95-99.

Kiewra, K. A. (1984). Implications for notetaking based on relationships between notetaking variables and achievement measures. Read. Improv, 21, 145-149.

Kiewra, K. A. (1985). Learning from a lecture: an investigation of note taking, review and attendance at a lecture. Human Learning, 4, 73-77.

Kiewra, K. A. (1987). Note taking and review: The research and its implications. Journal of Instructional Science, 16, 233-249.

Kiewra, K. A. (1989). A review of note taking. The encoding storage paradigm and beyond. Educational Psychology Review, 1, 147-172.

Kiewra, K. A. (2005). Learn how to study and SOAR to success. Upper Saddle River, NJ: Pearson Prentice Hall

Kiewra, K.A., Benton, S.L., Kim, S., Risch, N., \& Christensen, M. (1995). Effects of note-taking format and study technique on recall and relational performance. Contemporary Educational Psychology, 20, 172-187.

Kobayashi, K. (2005). What limits the encoding effect of note-taking? A meta-analytic examination. Contemporary Educational Psychology, 30, 242-262.

Kobayashi, K. (2006). Combined effects of note-taking/-reviewing on learning and the enhancement through interventions: A meta-analytic review. Educational Psychology, 26, 459-477.

Konrad, M., Joseph, L. M., \& Eveleigh, E. (2009). A meta-analytic review of guided notes. Education and Treatment of Children, 32(3), 421-444. 
Köğce, D. (2017). Sınıf öğretmenlerinin matematik derslerinde proje görevi verme amaçları ve proje görevi verirken dikkate aldıkları faktörler. Ö. Demirel ve S. Dinçer içinde, Eğitim bilimlerinde yenilikler ve nitelik araylşı (s. 893-908) Ankara: Pegem Akademi.

Magno, C. (2010). The effect of scaffolding on children's reading speed, reading anxiety, and reading proficiency. TESOL Journal, 3, 92-98.

Nakayama, M., Mutsuura, K. and Yamamoto, H. (2016). Lexical analysis of student's learning activity during the giving of instructions for note-taking in a blended learning environment. IIJET, 6 (1), 1-6.

Oğuz, A. (1999). Derste not almanın öğrenme ve hatırlama düzeyine etkisi. Yayımlanmamış Doktora Tezi. Hacettepe Üniversitesi Sosyal Bilimler Enstitüsü.

Pardini, E. A., Domizi, D. P., Forbes, D. A., \& Pettis, G. V. (2005). Parallel note-taking: A strategy for effective use of Webnotes. Journal of College Reading and Learning, 35, 38-55.

Petty, L., Sykes, K. \& Dugger, L. (2017). Use of Infographics to Support Note Taking. In P. Resta \& S. Smith (Eds.), Proceedings of Society for Information Technology \& Teacher Education International Conference (pp. 1752-1756). Austin, TX, United States: Association for the Advancement of Computing in Education (AACE).

Retrieved April 13, 2018 from https://www.learntechlib.org/p/177458/.

Poorahmadi, M. (2010). The effect of employing scaffolding strategies and classroom tasks in teaching reading comprehension. The Journal of TEFLL, 1(3), 87-106.

Quintus, L., Borr, M., Duffield, S., Napoleon, L., \& Welch, A. (2012). The impact of the Cornell notetaking method on students' performance in a high school family and consumer sciences class. Journal of Family and Consumer Sciences, 30(1), 27-38.

Rachal, K. C., Daigle, S., \& Rachal, W. S. (2007). Learning problems reported by college students: Are they using learning strategies? Journal of Instructional Psychology, 34, 191-199.

Robinson, C. (2018). Note-taking strategies in the science classroom. Science Scope, 41(6), 22-25.

Robinson, D. H., Katayama, A. D., Odom, A. B. S., His, Y., \& Vanderveen, A. (2006). Increasing text comprehension and graphic note taking using a partial graphic organizer. Journal of Educational Research, 100, 103-111.

Tabak, G. ve Karadüz, G. (2016). Türkçe öğretmeni adaylarının dinlerken not alma stilleri. Ana Dili Ĕgitimi Dergisi, 4(1), 73-83.

Tashakkori, A. \& Creswell, J. (2007). Exploring the nature of research questions in mixed methods research. Journal of Mixed Methods Research, 1(3), 207-211.

Williams, R. L. \& Worth, S. L. (2002). Thinking skills and work habits: Contributors to course performance. The Journal of General Education, 51(3), 200-227.

Wittrock, M. C. (1989). Generative processes of comprehension. Educational Psychologist, 24(4), 345376.

Yazıcıoğlu. Y. \& Erdoğan, S. (2004). SPSS uygulamalı bilimsel araştırma yöntemleri. Ankara: DetayYayincilik.

Yıldırım \& Şimşek (2005). [Sosyal Bilimlerde Nitel Araştırma Yöntemleri (2. baskı). Ankara: Seçkin Yayıncilik. 


\section{Extended Abstract}

\section{Introduction}

Learners need to take notes in order to ensure the permanence of the topics in the lecture process and review the topics after the lecture since reviewing the notes taken in writing is easy to keep in mind. Reviewing ensures that students consolidate the information noted, re-interpret course topics, and remember forgotten information. However, if the notes that students took is not qualified, reviewing process will not be efficient.

In the process of listening lecture and note-taking, it is observed that learners have difficulty in selecting important information or placing the note under the heading associated with the relevant subject. It is recommended that instructors should provide holistic or sectional notes related with subjects to the students due to their poor note-taking skills.

Using organized scaffolding technique is an effective process of interpretation that allows the students to reorganize by unifying the knowledge with preliminary knowledge. To prevent this difficulty, lecturers are expected to organize the education in order to ease the learning. In the study, the relationship between note-taking styles and academic achievement of the participants was aimed to detect.

\section{Methodology}

In this study, a mixed method is used which is a combination of qualitative and quantitative researchers. The influence of the note-taking habits of the first year undergraduates who enrolled in the department of guidance and psychological counseling, faculty of education in a state university was investigated to understand the effect of scaffolding technique on students' note-taking skills and performance. Participants in the experimental group were asked to take notes on the note forms prepared with the organized scaffolding technique in which the outline of the subject was organized, and the note-taking style of the participants in the control group was left to individual preferences.

Quantitative analysis allows the researchers to make a comparison between variables. The quantitative dimension of the study was formed according to the pattern of control and experimental groups. Within this context, the study was modeled according to control group trial pattern with pretest/posttest. In the qualitative dimension of the study, semi-structured interviews were conducted with 14 students from both control and experimental groups in total and questions were asked related to their note-taking preferences.

The working group of the study consisted of the first-year students who attended the department of guidance and psychological counseling of a state university's education faculty. Control and the experimental group consisted of 60 students in total with 30 students in each group. The scores of University Entrance Exam and pre-test scores of the participants were taken into account when the experimental and control groups were formed.

Three data collection tools related to basic aim and sub problems of the study were used. The first of these is note-taking forms for students, the second one is subject area performance test and the last one is semi-structured interview form. In order to determine the 
relation between the way students take notes and their subject area performances, organized scaffolding note-taking forms were prepared by using the studies in the field and the opinions of 3 field experts were taken to evaluate the validity and understandability of the coverage. Final forms for the organized scaffolding note-taking forms were given according to the feedback from field experts. In the process of data collection, Freud and His theories were orally explained and Control subjects were asked to take notes freely while following the subjects. Students in the experimental group were given note-taking forms, which were prepared based on organized scaffolding note-taking technique and were told to fill the forms with the information they get from the lecture. After the students have completed all these procedures, the forms in which both groups have graded have been evaluated by grading assessment rubrics. The note papers were evaluated by the two evaluators using the prepared rubric and the average of the scores given by both gave the scores of the students. Finding a correlation of 0.74 between the scorers revealed a high correlation at the 0.01 level.

In both experimental and control groups, "Freud \& His theories" was studied in the course of Educational Psychology for 3 weeks. An achievement test was prepared and it was checked by the experts on subject-area. In this direction, the question variety was sought in terms of measurement and evaluation reliability in the subject area performance test. Questions were graded as 5 to 10 points according to their usefulness. There were 15 questions in subject area performance test and opinions of experts were taken for the prepared draft test. The Cronbach Alpha reliability coefficient of the subject area performance test applied at the final stage of the study is .83 .

Semi-structured interview forms that were used in interviews with 14 students from both control and experimental groups were resolved by researchers, themes were created and frequencies and percentages were calculated.

\section{Findings}

Analysis of the data collected in the study revealed that the independent t-test results between the note-taking scores of the experimental and control groups showed a significant difference. The average note-taking scores of the experimental group (6.7) were higher than the average note-taking scores of the control group (4.16). The corrected average of subject area performance test scores of experimental and control group participants are 68.73 and 51.92 respectively.

The ANCOVA results of the groups show that there was a significant difference between the posttest performance scores of the experimental and control groups and the average scores of the groups change when the note-taking scores were controlled.

It was possible to mention that scattering plot of the experimental group demonstrated a positive relationship between the note-taking and performance scores of the experimental group. It was not possible to mention that the control group had any relationship between the notetaking and subject area performance scores. It was inferred that there was a strong, positive and significant relationship between the note-taking scores and the performance scores of the experimental group. The correlation coefficient was calculated as $r=.821$. Accordingly, it could be said that the note-taking score of the students in the experimental group increased as the performance scores increased. 
In the qualitative findings of the students of the experimental group, which were provided to take notes by using the Organized scaffolding technique, they stated that they could master the whole of the subject $(72 \%)$ by using the distributed note forms that they could relate the information they had earlier with the information on the notepaper (72\%). Since some important points related to the contents are given in the note-taking forms prepared according to organized scaffolding technique, students can adapt to the speed of lecturing of the instructor (100\%) and take more organized notes (86\%). Furthermore, students stated that they can focus better on the class $(86 \%)$ and they can recall figures and images better in the notes they took afterward $(72 \%)$.

The control group, which semi-structured interviews have been made stated that students were experiencing problems in writing notes fast enough (86\%) and instructors getting up to speed (72\%). In addition to this, when the preliminary information on the subject was not sufficient, they mentioned that they cannot distinguish which information is more important $(86 \%)$ and that they cannot arrange their notes (58\%). Students also stated that they could not recall the information they missed during the note-taking process $(100 \%)$ and that it was difficult to repeat the notes after the course (72\%).

\section{Discussion}

The note-taking is an important strategy in ensuring the permanence of learned information and learning. However, it is understood that students have poor note-taking skills from either the results of our study or the studies in the literature. Therefore, it is necessary for lecturers to use various methods to ensure students to take qualified notes. In this study, it was seen that organized scaffold note-taking technique helps the students to take qualified notes. It has also been seen that it is an effective method for understanding and remembering what they listen to. Other note-taking methods such as Cornell, the integrated note-taking system, and the split-page method can be used to perform comparative studies on the effect of organizer scaffolding on note-taking. The results of the students' preferences for all these methods and the reasons for their preference may provide important data to those who prepare course tools, teachers who give presentations and researchers. 
Ek-1 Örnek Form

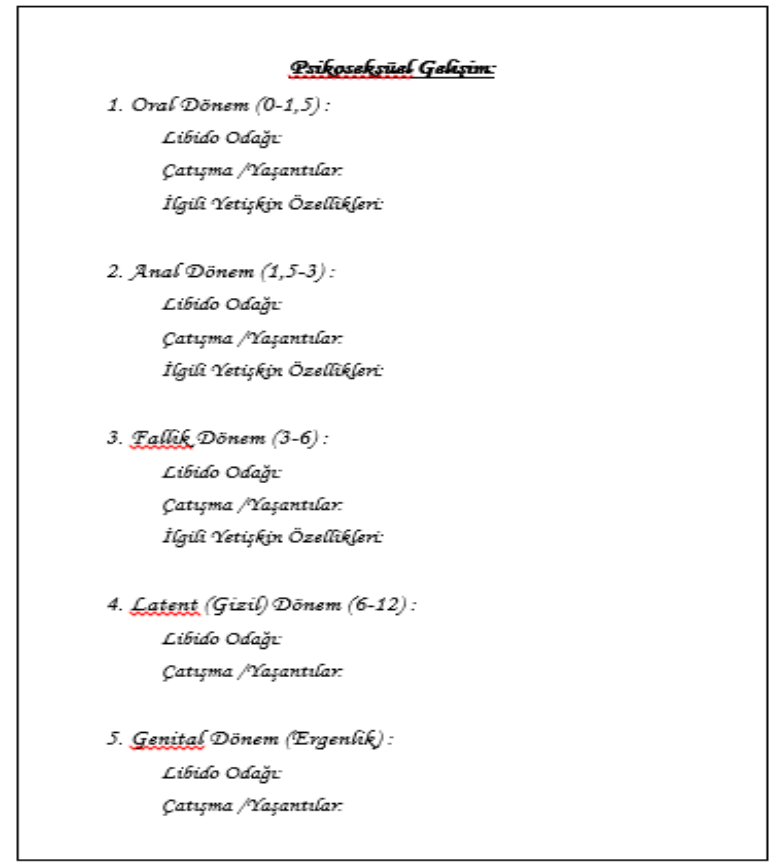

Ek-2 Örnek Öğrenci Notu

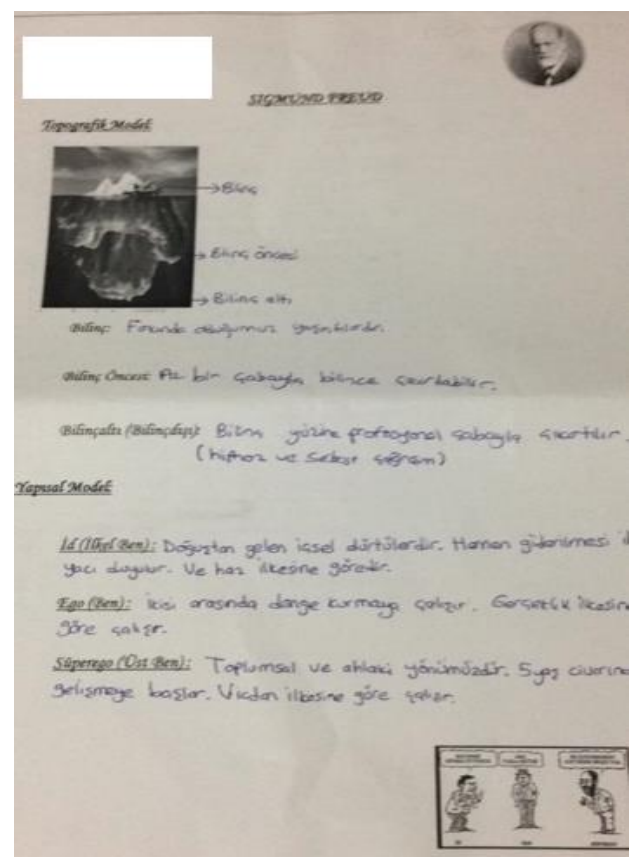

